\title{
Pelatihan Penggunaan "BAKUTEKU” sebagai Pengganti Folder Penyimpanan Arsip Warga Tidar Sari Kota Magelang
}

\section{Dian Fithra Permana*1, Ahmad Saeroji'², Shelahiya ${ }^{3}$}

1,2,3Program Studi Pendidikan Ekonomi, Fakultas Ekonomi, Universitas Negeri Semarang, Indonesia *e-mail: $\underline{\text { dianfithrapermana@mail.unnes.ac.id }}{ }^{1}{ }_{\text {saeroji@mail.unnes.ac.id }}^{2}{ }^{2}$ shelahiya@student.unnes.ac.id $^{3}$

\begin{abstract}
Abstrak
Pengabdian ini dilaksanakan dengan didasarkan pada banyaknya individu yang menyimpan arsip surat-surat berharga dengan menumpuknya di dalam satu map dan hanya diletakkan di dalam lemari tanpa perawatan tertentu sehingga arsip tersebut rentan terhadap kerusakan. Warga Tidar Sari Kota Magelang khususnya banyak yang masih menyimpan arsip surat berharga mereka dengan metode yang demikian, sehingga ketika arsip tersebut dibutuhkan untuk digunakan cenderung sudah menemui kerusakan pada arsip tersebut. Penulis mencoba mengembangkan folder penyimpanan arsip menjadi suatu produk bernama "BAKUTEKU" (Baca Aku Temukan Aku) agar proses penyimpanan arsip dapat berjalan dengan baik, arsip terhindar dari kerusakan dan mudah untuk ditemukan kembali khususnya bagi warga Tidar Sari kota Magelang. Pengabdian dilaksanakan dengan melakukan pemaparan materi mengenai kearsipan dan pelatihan penggunaan BAKUTEKU. Hasil dari pengabdian ini menjadikan warga Tidar Sari kota Magelang menjadi lebih memahami pentingnya arsip dan dapat menyimpan arsip dengan baik, menjaga dan melindungi arsip yang disimpan dengan penyimpanan yang lebih terstruktur dan dapat dengan mudah ditemukan kembali.
\end{abstract}

Kata kunci: Arsip, BAKUTEKU, Folder, Penyimpanan

\begin{abstract}
This devotion is carried out based on the number of individuals who keep archives of securities by stacking them in a folder and only placed in a closet without certain care so that the archive is vulnerable to damage. Residents of Tidar Sari Magelang City in particular many still keep their securities archive by such methods, so when the archive is needed for use tends to have encountered damage to the archive. The servicer tried to develop the archive storage folder into a product called "BAKUTEKU" (Read me and Found Me) so that the archive storage process can run well, the archive avoids damage and is easy to rediscover, especially for the residents of Tidar Sari magelang city. The service is carried out by conducting material presentations on archival and training in the use of BAKUTEKU. The result of this devotion makes the citizens of Tidar Sari magelang city become more understanding of the importance of archives and can store archives well, maintain and protect archives stored with more structured storage and can be easily rediscovered.
\end{abstract}

Keywords: Archive, BAKUTEKU, Folder, Storage

\section{PENDAHULUAN}

Kehidupan dalam suatu organisasi atau seseorang tidak pernah terlepas dari kebutuhan akan informasi. Pada dasarnya semua kegiatan yang dilakukan seseorang membutuhkan informasi sebagai pendukung administrasi yang dibutuhkan dalam kehidupan bermasyarakat. Salah satu sumber informasi yang dibutuhkan oleh seseorang dapat diperoleh dari arsip, yang proses pengelolaanya disebut kearsipan. Istilah arsip seperti diungkapkan oleh A.W Widjaja (1986: 99) berasal dari bahasa Yunani, yaitu dari kata arche, kemudian menjadi archea dan selanjutnya mengalami perubahan kembali menjadi archeon. Archea berarti dokumen atau catatan mengenai permasalahan. Dalam bahasa Inggris disebut archives yang berarti tempat atau dokumen. Sedangkan menurut Kamus Administrasi Perkantoran arsip adalah kumpulan dokumen yang disimpan secara teratur, berencana, karena mempunyai suatu kegunaan agar setiap kali dibutuhkan dapat ditemukan kembali secara cepat. UU No. 43 tahun 2009 mengenai kearsipan menyebutkan pengertian arsip sebagai berikut. Arsip adalah rekaman kegiatan atau peristiwa dalam berbagai bentuk dan media sesuai dengan perkembangan teknologi informasi dan komunikasi yang dibuat dan diterima oleh lembaga negara, pemerintahan daerah, lembaga 
pendidikan, perusahaan, organisasi politik, organisasi kemasyarakatan, dan perseorangan dalam pelaksanaan kehidupan bermasyarakat, berbangsa, dan bernegara. (http://dunia arsip.com 811-2012). Selain itu arsip merupakan versi lengkap dari pekerjaan dan semua bahan tambahan yang disimpan setelah publikasi awal di setidaknya satu repositori online yang didukung oleh akademisi lembaga, civitas akademika, instansi pemerintah, atau organisasi mapan lainnya yang berusaha untuk memungkinkan akses terbuka, distribusi tidak terbatas, interoperabilitas, dan jangka panjang pengarsipan (Suber, 2003). Bidang kearsipan sendiri mengalami perkembangan, maka muncul banyak ahli yang mencoba mengemukakan pendapat-pendapatnya mengenai arsip. Dengan demikian kearsipan menjadi suatu kegiatan yang sangat penting. Hal ini sangat disadari, karena seseorang akan terkendala apabila sistem kearsipannya tidak baik. Kegiatan kearsipan tidak akan pernah terlepas dari pengelolaan arsip. Arsip mempunyai peranan penting dalam proses penyajian informasi untuk kepentingan perorangan dalam rangka memenuhi kebutuhan administrasi yang dituntut dalam kehidupan bermasyarakat. Oleh sebab itu untuk dapat menyajikan informasi yang lengkap, cepat, dan benar harus ada sistem yang baik di bidang kearsipan.

Kearsipan memiliki tujuan untuk menjamin keselamatan bahan pertanggungjawaban mengenai perencanaan, penyelenggaraan kehidupan seseorang serta untuk menyediakan bahan pertanggungjawaban yang diperlukan bagi seseorang. Menurut Sularso Mulyono (1985: 1), yang disebut arsip secara umum adalah "1. Tempat untuk menyimpan berkas sebagai bahan pengingatan, 2. Bahan-bahan, baik berwujud surat, laporan, perjanjian-perjanjian, gambargambar hasil kegiatan, statistik, kuitansi dan sebagainya, yang disimpan sebagai bahan pengingatan". Salah satu jenis arsip yang intensitas penggunaannya masih tinggi dan merupakan salah satu sumber informasi utama bagi seseorang adalah surat-surat penting atau surat berharga yang dimiliki seseorang. Agus Sugiarto \& Teguh Wahyono (2005: 7) mengungkapkan arsip disini adalah setiap catatan (record/dokumen) yang tertulis, tercetak, atau ketikan dalam bentuk huruf, angka atau gambar, yang mempunyai arti dan tujuan tertentu sebagai bahan komunikasi dan informasi, yang terekam pada kertas (kartu, formulir), kertas film (slide, filmstrip, mikrofilm), media computer (disket, pita magnetic, piringan), kertas photocopy, dan lainlain. Pendapat lain dikemukakan oleh Basir Barthos (2003: 1), di dalam bukunya yang berjudul Manajemen Kearsipan mengemukakan arsip adalah "setiap catatan tertulis baik dalam bentuk bagan atau gambar yang memuat keterangan-keterangan mengenai suatu subjek (pokok persoalan) ataupun peristiwa yang dibuat orang untuk membantu daya ingatan orang (itu) pula". Dengan demikian arsip tersebut harus dikelola dengan baik karena masih digunakan secara langsung dalam pemenuhan kebutuhan administratif seseorang. Informasi yang dibutuhkan tentang kebijakan pengarsipan sebagai alat advokasi untuk mendorong praktik pengarsipan dan untuk mengirimkan pesan yang jelas tentang apa arti pengarsipan dan memungkinkan akses terbuka dalam kearsipan (Jenkins, 2007). Menyadari pentingnya arsip bagi kelangsungan hidup seseorang, dalam hal ini arsip dipandang ip sebagai alat pengingat dan sumber informasi yang dapat membantu seseorang dalam pemenuhan kebutuhan administratifnya. Setiap individu dituntut dapat mengetahui intensitas penggunaan arsip yang dimilikinya agar informasi yang dibutuhkannya dapat mudah untuk ditemukan, dan tujuan dari individu tersebut dapat tercapai. Banyak warga masyarakat yang masih menganggap bahwa arsip merupakan hal yang kurang penting. Sehingga dalam proses pengelolaannya kurang mendapatkan perhatian. Banyak individu-individu yang menyimpan arsip surat-surat berharga mereka dengan menumpuknya di dalam satu map dan hanya diletakkan di dalam lemari tanpa perawatan tertentu sehingga arsip tersebut rentan terhadap kerusakan.

Warga Tidar Sari Kota Magelang khususnya banyak yang masih menyimpan arsip surat berharga mereka dengan metode yang demikian, sehingga ketika arsip tersebut dibutuhkan untuk digunakan cenderung sudah menemui kerusakan pada arsip tersebut. Endang Wiryatmi Tri Lestari (1993: 75), mengungkapkan Prinsip penyimpanan arsip adalah "aman, awet, up to date, dan efisien. Penyelenggaraan kearsipan tiap organisasi berbeda-beda, sesuai dengan kebutuhannya". Hal di atas menunjukkan bahwa memang kearsipan sekarang ini belum mencapai hasil yang diinginkan, masih terpinggirkan dan butuh pengelolaan lebih baik mengenai pelaksanaan pengelolaannya agar di kemudian hari pengelolaan arsip dapat 
dipandang seutuhnya sebagai sesuatu yang urgent dan sangat dibutuhkan dalam pencapaian tujuan seseorang. Salah satu cara dalam menyimpan arsip surat berharga bagi seseorang adalah dengan folder yang mana arsip disimpan pada suatu map yang di dalamnya terdapat plastikplastik pelindung untuk meletakkan arsip agar dapat terlindung dari kerusakan. Akan tetapi penggunaan folder sendiri masih masih dirasa kurang efektif dalam prosess penemuan kembali arsip surat berharga yang dibutuhkan. Peletakkan arsip secara acak tanpa terindeks membuat seseorang kesulitan dalam menemukan kembali arsip yang dibutuhkan. Hal tersebut pula yang terjadi pada warga Tidar Sari kota Magelang dalam penemuan kembali arsip yang dibutuhkan. Sulistyo-Basuki (2003: 220), menyebutkan sistem manajemen keamanan memiliki sasaran sebagai berikut: a) Memberikan kerahasiaan informasi dan data tentang pribadi, miliki, atau yang bersifat sensitive b) Menyediakan integritas isi arsip dinamis dan ketepatan data c) Mencegah upaya akses tidak berkewenangan terhadap sistem dan data d) Akses yang cepat bagi pemakai sah pada informasi dan data. Cara lain adalah dengan sistem warna pengarsipan diri putih, kuning dan hijau -dikembangkan selama Proyek RoMEO asli (Gadd et al., 2004) dan banyak digunakan di open mengakses lingkaran. Ini dikembangkan untuk digunakan dalam database SHERPA/RoMEO dengan penambahan "biru". Penerbit diberi warna pengarsipan diri tertentu, tergantung pada apa yang mereka izinkan untuk diarsipkan sendiri. istilah dan definisi pengarsipan diidentifikasi dan dimasukkan ke dalam kategori, dan kosakata terkontrol yang dihasilkan dikembangkan (Jenkins et al., 2006). Untuk itu dibutuhkan inovasi yang baik mengenai cara penyimpanan arsip bagi seseorang khususnya dalam hal ini bagi warga Tidar Sari kota magelang agar mereka dapat menyimpan arsip dengan baik, terhindar dari kerusakan dan mudah dalam menemukan kembali arsip. Folder saja dirasa kurang efektif untuk mewujudkan hal tersebut. Untuk itu peneliti mencoba mengembangkan Folder menjadi suatu produk bernama "BAKUTEKU" (Baca Aku Temukan Aku) agar proses penyimpanan arsip dapat berjalan dengan baik, arsip terhindar dari kerusakan dan mudah untuk ditemukan kembali khususnya bagi warga Tidar Sari kota Magelang yang masih mengalami kendala dalam penyimpanan arsip. Dari uraian tersebut penulis bermaksud melakukan pengabdian kepada masyarakat dengan judul “Pelatihan Penggunaan 'BAKUTEKU' sebagai Pengganti Folder Penyimpanan Arsip Warga Tidar Sari Kota Magelang".

Berdasarkan permasalahan warga Tidar Sari Kota Magelang terkait dengan sistem penyimpanan arsip yang masih kurang tertata dengan baik, banyak terjadi kerusakan arsip penting, dan juga sulitnya penemuan Kembali arsip yang diinginkan, maka solusi yang dapat ditawarkan membuat pelatihan penyimpanan arsip melalui BAKUTEKU "Baca Aku Temukan Aku" yaitu sistem penyimpanan arsip yang merupakan pengembangan dari folder dimana di dalam folder tersebut terdapat plastik-plastik pelindung dan berguna sebagai tempat penyimpanan arsip agar terhindar dari kerusakan sekaligus memisahkan arsip yang satu dengan yang lainnya agar tidak bercampur. Dibagian luar folder tersebut terdapat tempat - tempat kartu yang bisa ditulis secara manual jenis arsip yang disimpan dengan warna yang diinginkan dan disesuaikan dengan warna sekat pembatas pada bagian arsip yang disimpan agar penemuan Kembali arsip tersebut dapat dilakukan dengan mudah.

\section{METODE}

Ada lima tahapan yang dilaksanakan dalam pengabdian ini dari awal hingga akhir seperti yang digambarkan pada bagan Gambar 1.

Berikut ini adalah penjelasan detail mengenai Gambar 1.

1. Pemetaan masalah dilaksanakan oleh penulis mengenai masalah kearsipan yang dihadapi oleh warga Tidar Sari kota Magelang.

2. Koordinasi dengan kepala desa warga Tidar Sari Kota Magelang mengenai pelatihan teknis pengabdian yang akan dilakukan khususnya mengenai pelatihan yang akan dilaksanakan.

3. Mengkaji pemahaman warga Tidar Sari mengenai pentingnya arsip dengan melakukan pemaparan materi kearsipan dan menarik pemahaman setelah pemaparan materi. 
4. Pelatihan cara menggunakan BAKUTEKU sebagai alat penyimpanan arsip bagi warga Tidar Sari Kota Magelang.

5. Melakukan evaluasi terhadap pengabdian yang telah dilakukan dengan menganalisis kekurangan apa yang muncul selama pelaksanaan pengabdian.

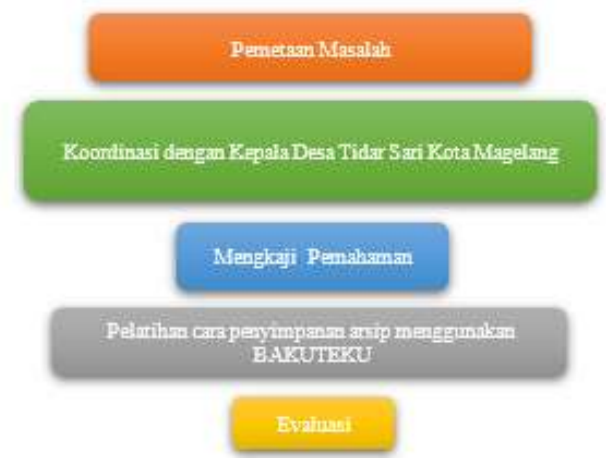

Gambar 1. Prosedur kerja pengabdian masyarakat pelatihan penggunaan BAKUTEKU

\section{HASIL DAN PEMBAHASAN} Magelang.

Berikut adalah tahapan pelatihan penggunaan BAKUTEKU pada warga Tidar Sari Kota

\subsection{Pemetaan Masalah}

Pemetaan masalah dilakukan penulis dengan melakukan survey secara langsung pada warga Tidar Sari Kota Magelang mengenai permasalahan apa yang dihadapi warga mengenai kearsipan. Selain survey juga dilakukan sedikit wawancara kepada warga Tidar Sari Kota Magelang mengenai hal tersebut. Dari hasil survey dan wawancara ditemukan permasalahan mengenai penyimpanan arsip warga Tidar Sari Kota Magelang dimana warga masih menyimpan arsip khususnya surat - surat penting dengan cara ditumpuk begitu saja di lemari kayu sehingga rentan terdapat kerusakan dan apabila dibutuhkan Kembali dirasa sulit dalam menemukan Kembali arsip yang dibutuhkan tersebut.

\subsection{Koordinasi dengan Kepala Desa Tidar Sari Kota Magelang}

Setelah ditemukan permasalahan mengenai kearsipan di warga Tidar Sari Kota Magelang maka penulis melakukan koordinasi dengan kepala desa warga Tidar Sari Kota Magelang mengenai solusi yang akan dilakukan untuk mengatasi masalah. Dalam hal ini penulis berkoordinasi mengenai pelatihan yang akan dilakukan untuk membenahi cara penyimpanan arsip warga Tidar Sari Kota Magelang. Penulis berkoordinasi mengenai pelatihan yang akan dilakukan yaitu pelatihan penggunaan BAKUTEKU sebagai pengganti folder penyimpanan arsip yang dirasa dapat menjadi solusi mengenai permasalahan penyimpanan arsip yang dihadapi. Kemudian berkoordinasi mengenai peserta yang akan mengikuti pelatihan tersebut dan bagaimana teknisnya. Dalam hal ini kepala desa warga Tidar Sari menginstruksikan untuk melakukan pelatihan dengan jumlah peserta 20 orang dengan teknis tatap muka sebanyak peserta 10 orang dan door to door sebanyak 10 orang dikarenakan masih dalam kondisi pandemic COVID-19.

\subsection{Mengkaji Pemahaman}

Mengkaji pemahaman kearsipan dilaksanakan dengan melakukan pemaparan materi mengenai kearsipan sebelum melakukan pelatihan. Penulis melakukan presentasi dan pemaparan mengenai materi-materi arsip dan kearsipan, bagaimana penyimpanan arsip yang baik dan benar, dan bagaimana mengamankan arsip dengan benar. Berikut adalah foto kegiatan pemaparan materi yang dilakukan penulis. 


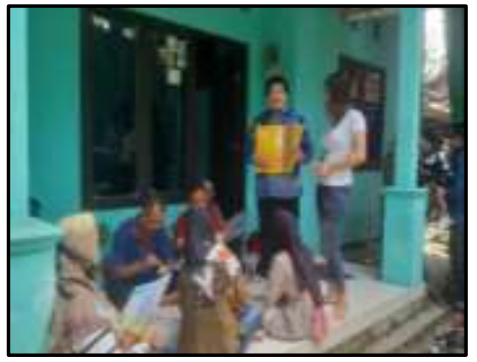

(a)

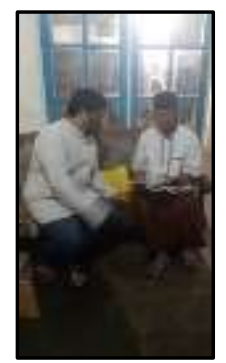

(b)

Gambar 2. Pelaksanaan Pemaparan Materi Kearsipan (a) pemaparan materi secara tatap muka (b) pemaparan materi secara door to door

Gambar (a) merupakan pelaksanaan tahap pengabdian mengkaji pemahaman dengan cara memaparkan materi - materi mengenai kearsipan secara tatap muka dengan peserta 10 orang. Kemudian Gambar (b) merupakan pelaksanaan kegiatan mengkaji pemahaman dengan cara pemaparan materi kearsipan secara door to door ke rumah warga. Adapun materi yang dipaparkan meliputi pengertian arsip dan kearsipan, bagaimana cara menyimpan arsip yang baik dan benar, dan juga bagaimana mengamankan arsip dengan baik agar terhindar dari kerusakan. Dari hasil pemaparan maka dapat ditarik pemahaman kearsipan warga Tidar Sari Kota Magelang yang lebih meningkat.

\subsection{Pelatihan Cara Penyimpanan Arsip menggunakan BAKUTEKU}

Sebelum membahas mengenai pelaksanaan pelatihan penggunaan BAKUTEKU penulis akan membahas terlebih dahulu apa itu BAKUTEKU. BAKUTEKU merupakan singkatan dari "BACA AKU TEMUKAN AKU" yaitu sistem penyimpanan arsip yang merupakan pengembangan dari folder dimana di dalam tools BAKUTEKU tersebut terdapat plastik-plastik pelindung dan berguna sebagai tempat penyimpanan arsip agar terhindar dari kerusakan sekaligus memisahkan arsip yang satu dengan yang lainnya agar tidak bercampur. Dibagian luar tools BAKUTEKU tersebut terdapat tempat-tempat kartu berwarna - warni yang bisa ditulis secara manual dimana dapat ditulis jenis arsip yang disimpan dengan warna yang diinginkan sesuai dengan keinginan individu hal ini bertujuan agar individu tahu urutan letak penyimpanan arsipdi dalam BAKUTEKU sesuai urutan warna kartu pada sampul BAKUTEKU sehingga memudahkan penemuan kembali arsip yang disimpan. Berikut adalah gambar tahapan pembuatan tools BAKUTEKU.

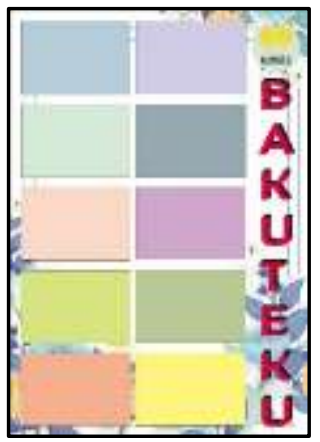

(a)

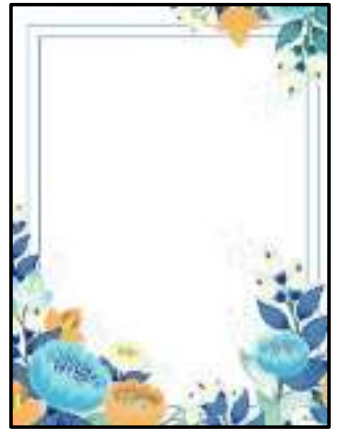

(b)

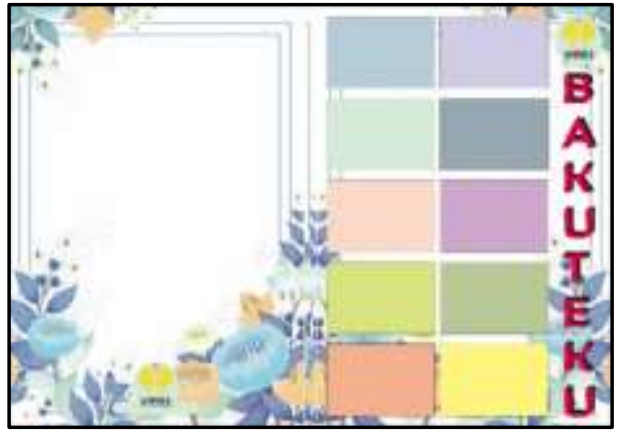

(c)

Gambar 3. Desain Produk BAKUTEKU (a) sampul depan (b) sampul belakang (c) desain utuh

Hal pertama yang dilakukan untuk membuat tools BAKUTEKU adalah mendesain bagian luar atau sampul yang nantinya akan di tempel Di bagian luar fileholder sebagai tempat penyimpanan arsip. Gambar (a) menunjukkan desain sampul depan dimana terdapat kotakkotak warna - warni yang bertujuan sebagai space untuk tempat kartu penamaan arsip. Gambar (b) merupakan desain sampul belakang tools BAKUTEKU dan gambar (c) adalah desain utuh 
tools BAKUTEKU yang nantinya akan di printout dengan bahan sticker yang kemudian di tempel pada fileholder tempat penyimpanan arsip.

Setelah desain selesai dibuat, kemudian di printout dengan bahan sticker yang selanjutnya ditempelkan pada fileholder penyimpanan arsip. Selain menempel hasil desain tersebut penulis juga menempelkan plastik tempat penyimpanan kartu pada bagian kotak-kotak warna-warni pada sampul bagian depan sesuai dengan ukuran kotak warna-warni tersebut yaitu 10 x $5 \mathrm{~cm}$. Penulis juga menyiapkan kartu dari bahan kertas Ivory untuk dimasukkan dalam plastic tersebut sesuai dengan warna kotak yang terdapat dalam sampul dengan ukuran $9.5 \times 4.5 \mathrm{~cm}$. kertas ini yang nantinya digunakan untuk menulis secara manual jenis arsip yang disimpan. Berikut adalah gambar dari produk BAKUTEKU yang telah jadi.

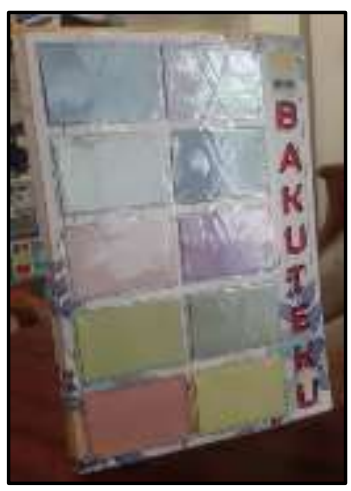

(a)

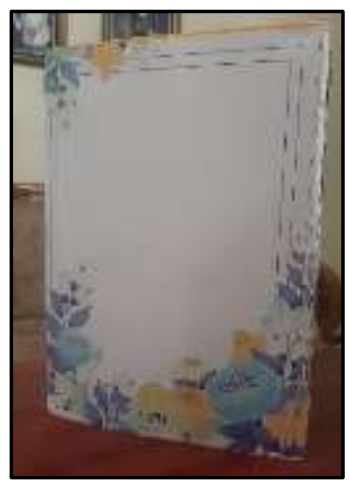

(b)

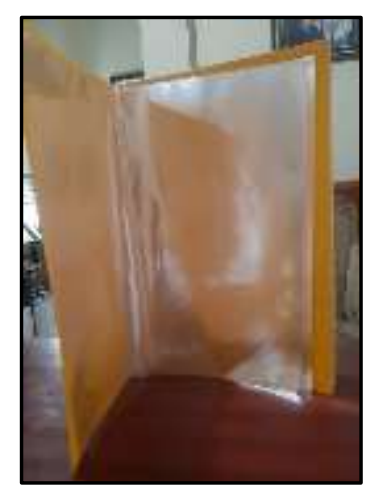

(c)

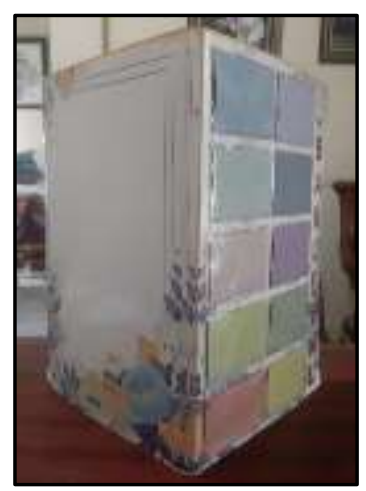

(d)

Gambar 4. Produk BAKUTEKU (a) Bagian depan produk (b) Bagian belakang produk (c) Bagian dalam produk (d) Bagian luar produk

Gambar (a) merupakan bagian depan BAKUTEKU yaitu terdapat kotak warna - warni yang telah dilengkapi tempat penyimpanan kartu dari plastik dan diisi kartu sesuai dengan warna kotak untuk menuliskan nama atau jenis arsip yang akan disimpan. Gambar (b) adalah bagian belakang dari BAKUTEKU. Gambar (c) adalah bagian dalam dari BAKUTEKU terdapat plastic-plastik untuk menyimpan arsip agar awet dan terhindar dari kerusakan. Gambar (d) merupakan gambar keseluruhan penampakan bagian luar dari produk BAKUTEKU.

Setelah produk/tools BAKUTEKU berhasil dibuat dan diselesaikan maka kemudian digunakan dalam pelatihan penggunaan BAKUTEKU sebagai sarana penyimpanan arsip penting pada warga Tidar Sari Kota Magelang. Berikut adalah gambar dari pelaksanaan pelatihan penggunaan BAKUTEKU.

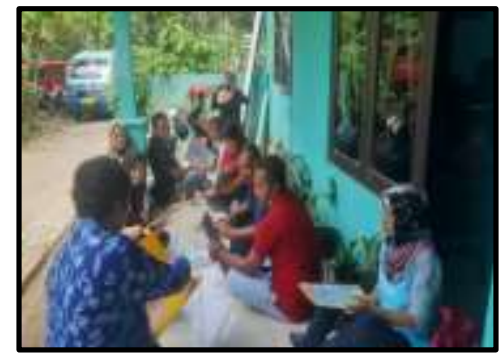

(a)

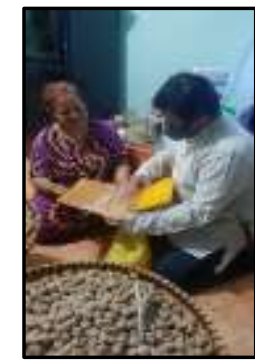

(b)

Gambar 5. Pelaksanaan Pelatihan Penggunaan BAKUTEKU (a) Pelatihan secara tatap muka (b) Pelatihan secara door to door

Gambar (a) merupakan gambaran situasi pelaksanaan pelatihan penggunaan BAKUTEKU sebagai pengganti folder penyimpanan arsip warga Tidar Sari Kota Magelang secara langsung tatap muka dengan jumlah peserta 10 orang saja dikarenakan adanya pembatasan kerumunan sebagai dampak pandemic COVID-19. Dalam pelatihan tersebut penulis mencontohkan bagaimana menyimpan arsip penting menggunakan BAKUTEKU. Misalnya menyimpan arsip 
Kartu Keluarga (KK) maka penulis mencontohkan dengan mengambil salah satu kartu pada sampul BAKUTEKU kemudian ditulis secara manual nama arsip yang akan disimpan (dalam contoh ini KK) maka ditulis Kartu Keluarga pada kartu tersebut. Setelah ditulis kemudian kartu masukkan Kembali pada plastik kartu sesuai warna kartu. Kemudian arsip KK tersebut dimasukkan pada bagian dalam BAKUTEKU pada sekat plastic sesuai dengan urutan kartu di sampul BAKUTEKU. Gambar (2) merupakan pelatihan yang sama, penulis mencontohkan hal yang sama akan tetapi dilakukan secara door to door dikarenakan sesuai arahan kepala desa dikarenakan dampak pandemi COVID-19 yang tidak memperbolehkan terjadi banyak kerumunan. Penulis melakukan pelatihan secara door to door dengan mengunjungi rumah rumah warga sebanyak 10 orang.

\subsection{Evaluasi}

Evaluasi yang dilakukan penulis adalah dengan cara melakukan diskusi dengan kepala desa Tidar Sari Kota Magelang, dan warga Tidar Sari Kota Magelang sendiri terkait hal apa saja yang perlu ditambahkan dari kegiatan pengabdian, yang kemudian didiskusikan dengan seluruh anggota pelaksanaan pengabdian.

Hasil diskusi dengan kepala desa Tidar Sari Kota Magelang dihasilkan masih kurangnya Batasan jumlah warga yang dapat mengikuti pelatihan. Perlu diketahui bahwa penulis hanya membatasi jumlah peserta sebanyak 20 orang dikarenakan keterbatasan waktu dan biaya. Oleh karena itu menurut kepala desa Tidar Sari Kota Magelang masih terlalu sedikit jumlah keikutsertaan warga dan masih sangat dimungkinkan bagi warga yang tidak mengikuti pelatihan masih belum dapat menyimpan arsip dengan baik dan masih menemui kerusakan arsip.

Hasil diskusi dengan warga Tidar Sari Kota Magelang menghasilkan masukkan mengenai produk BAKUTEKU. Warga menambahkan akan lebih baik jika terdapat sekat penunjuk pada setiap penyimpanan arsip dalam BAKUTEKU sesuai dengan warna kotak pada sampul bakuteku agar saat menemukan kembali arsip bisa lebih cepat lagi karena ada tanda warna yang sama antara warna kotak yang ditulis nama arsip dengan sekat tempat penyimpanan arsip.

Masukan-masukan dari kepala desa dan warga kemudian penulis diskusikan bersama anggota pengabdi yang kemudian disampaikan kepada instansi apa yang perlu disampaikan dan membuat perbaikan produk BAKUTEKU untuk kedepannya sehingga pelaksanaan pengabdian di masa mendatang bisa ditingkatkan lebih baik lagi.

\section{KESIMPULAN}

Setelah pelaksanaan pengabdian warga Tidar Sari Kota Magelang mulai memahami pentingnya arsip, dan dapat menyimpan arsip penting dengan baik, terhindar dari kerusakan, terstruktur, dan mudah ditemukan kembali. Warga Tidar Sari Kota Magelang juga dapat melakukan penyimpanan arsip dengan benar, yang semula hanya ditumpuk begitu saja dalam lemari dan rentan terhadap kerusakan setelah dilakukan pelatihan, warga Tidar Sari Kota Magelang dapat menyimpan arsip menggunakan BAKUTEKU sehingga arsip penting yang mereka miliki awet, terstruktur dalam penyimpanannya, dan juga mudah dalam penemuan kembali.

Dalam pelaksanaan pengabdian kedepannya perlu mencakup lebih banyak warga yang terlibat agar seluruh warga dapat mengikuti pelatihan dan mendapat pemahaman mengenai kearsipan dan penyimpanan arsip yang baik menggunakan BAKUTEKU, dan juga perlu dilakukan penambahan pada produk berupa sekat pembatas yang sewarna dengan kotak tempat memberi nama arsip Di bagian sampul agar lebih cepat lagi dalam menemukan arsip yang dibutuhkan.

\section{UCAPAN TERIMA KASIH}

Penulis mengucapkan terimakasih kepada warga desa Tidar Sari Kota Magelang atas antusiasme keikutsertaan dalam pengabdian ini, Rektor Universitas Negeri Semarang, Dekan 
Fakultas Ekonomi Universitas Negeri Semarang, dan Ketua Jurusan Pendidikan Ekonomi Universitas Negeri Semarang atas support dan bantuannya dalam pengabdian ini.

\section{DAFTAR PUSTAKA}

A.W., Widjaja. 1986. Administrasi Kearsipan Suatu Pengantar. Jakarta: CV Rajawali

Agus, Sugiarto \& Teguh, Wahyono. 2005. Manajemen Kearsipan Modern. Yogyakarta: Gava Media Badri Munir Sukoco. (2007). Manajemen Adminiistrasi Perkantoran Modern. Jakarta: Erlangga.

Bartos, Basir. 2003. Manajemen Kearsipan. Jakarta: PT Bumi Aksara

DPR RI \& Presiden RI. 2009. Undang-undang No. 43 Tentang Ketentuan Pokok-Pokok Kearsipan. Jakarta

Endang, Wiyartini Tri Lestari. 1993. Arsip Dinamis Dalam Arus Informasi. Yogyakarta: Arikha Media Cipta

Gadd, E., Oppenheim, C. and Probets, S. (2004), RoMEO Studies 5: IPR issues facing OAI data and service providers, The Electronic Library, Vol. 22 No. 2, pp. 121-38. RoMEO Studies 8: selfarchiving 131

Gie, The Liang. 2000. Adminstrasi Perkantoran Modern. Yogyakarta: Liberty. Yogyakarta

Jenkins, C., Oppenheim, C., Probets, S. and Hubbard, B. (2006), RoMEO studies 7: creation of a controlled vocabulary to analyse copyright transfer agreements, Journal of Information Science.

Jenkins, C., Probets, S., Oppenheim, C., \& Hubbard, B. (2007). RoMEO Studies 8: self-archiving. Program, 41(2), 124-133. doi:10.1108/00330330710742908

Sularso Mulyono, dkk. 1985. Dasar-Dasar Kearsipan. Yogyakarta: Liberty. Yogyakarta

Suber, P. (2003), Bethesda Statement on Open Access Publishing, available at: www.earlham.edu/peters/fos/bethesda.htm 